\title{
Analisis Manajemen Pengelolaan SMK Berbasis Sampah di SMK Kreatif Dompu International Islamic School
}

\author{
Rizky Amelia ${ }^{1 *}$, Nural Yuyun Mardiana $^{2}$ \\ ${ }^{1,2)}$ Institut Agama Islam Muhammadiyah Bima \\ *Corresponding Author: rizkyameliakiki40@yahoo.com
}

\begin{abstract}
ABSTRAK - Penelitian ini bertujuan untuk menguraikan manajemen pengelolaan SMK berbasis sampah di SMK kreatif International Islamic School yang berada di desa Dorebara Kecamatan Dompu Kabupaten Dompu. Penelitian ini menggunakan jenis penelitian kualitatif dengan metode analisis deskriptif yang menggunakan pengumpulan data seperti wawancara, observasi, dokumentasi. Hasil Penelitian menunjukan bahwa cara pengelolaan sampah yang dilakukan oleh SMK Kreatif International Islamic School adalah sudah memenuhi unsur-unsur manajemen dengan menggunakan fungsi-fungsi manajemen yaitu perencanaan, pengorganisasian, penggerakan, pengawasan, dan evaluasi. Perencanaan yang dilakukan dalam pengelolaan sampah ada 3 yaitu perencanaan jangka pendek, jangka menengah dan jangka panjang. Sedangkan untuk pengorganisasian yaitu adanya struktur organisasi yang memiliki tugas dan tanggung jawab masing-masing. Penggerakan yaitu tindakan membimbing dan mengarahkan guru dan siswa agar bekerja secara baik dan benar. Pengawasan yaitu melihat hasil dari kreatifitas-kreatifitas siswa serta pendapatan yang dihasilkan dari sampah, sedangkan evaluasi yaitu melihat dan menilai kembali hasil dari kinerja manajemen pengelolaan sampah.
\end{abstract}

Kata Kunci - Manajemen; Pengelolaan Sampah

\begin{abstract}
This study aims to describe the management of waste-based SMK management at the creative International Islamic School creative vocational school, and the place of research here is the international islamicschool creative vocational school located in dorebara village, Dompu district, Dompu regency. This study usesqualitative research with descriptive analysis methodsthat use data collection such as interviews, observations, documentation. The results of study show that the way of managing waste. The results of the study show that the way of waste management elements by using managemen function, namey planning, mobilization, supervison, evaluation. There are 3 plans in waste management, namely short-term, medium-term and long -term planning. As for the organization, namely the existence of an organization structure that has respective duties and responsibilities. Mobilization is the act of guiding and directing teachers and students to work properly and correctly. Supervision is to see the results of students to work. Properly and correctly. Supervision is to see results of student creativity and the income generated from wastre, while evaluation is to see and reassess the results of waste management performance.
\end{abstract}

Keywords - Management; Waste Management

\section{PENDAHULUAN}

Permasalahan lingkungan hidup merupakan masalah yang akan terus berkembang dan berproses. Salah satu masalah lingkungan yang sangat dekat dengan kehidupan sehari-hari adalah masalah sampah. Berbagai hasil dari 
aktivitas manusia dan makin bertambahnya jumlah penduduk mengakibatkan bahan buangan makin hari makin bertambah. Sampah seringkali menjadi sebuah persoalan yang rumit dalam masyarakat. Sampah bisa mengakibatkan pencemaran lingkungan seiring dengan bertambahnya jumlah penduduk perkotaan. ${ }^{1}$

Berdasarkan pengamatan peneliti di kabupaten Dompu, bahwa Dompu merupakan salah satu kabupaten di Provinsi NTB yang kurang bersih dikarenakan kurangnya kesadaran dan kepedulian masyarakat terhadap permasalah sampah yang masih bisa dikatakan rendah. Hal ini disebabkan karena masyarakat yang masih sering membuang sampah sembarangan. Sedangkan salah satu permasalahan lingkungan hidup adalah tentang kebersihan.

Pada umumnya masyarakat Dompu hanya mengatasi masalah sampah di lingkungan dengan cara menitikberatkan pada Tempat Pembuangan Sementara (TPS) yang kemudian jika sampah tersebut telah numpuk dan akan kemudian dipindahkan Ke Tempat Pembuangan Akhir (TPA) yang telah disediakan oleh pemerintah. Hal tersebut hanya akan menangani sampah dengan jangka sementara. Karena jika sampah pada tempat pembuangan akhir tersebut telah menumpuk maka akan mengakibatkan beberapa dampak negatif dari sampah diantaranya pencemaran lingkungan, bau yang tidak sedap dan timbulnya bibit penyakit. Untuk itu sangat diperlukan pengelolaan sampah yang baik dan benar. ${ }^{2}$ Salah satu cara pengelolaan sampah yang baik dan benar adalah dengan pendidikan berbasis sampah.

Pendidikan berbasis sampah telah hadir di Kabupaten Dompu. Pendidikan ini awal mulanya didirikan oleh seorang yang bernama Agus Setiawan atau biasa disapa dengan sebutan Abu Dzar. Beliau mengatakan, mengatasi masalah sampah plastik dengan cara membakarnya juga bukanlah solusi yang baik, meski dapat mengurangi jumlah sampah namun hal ini malah menimbulkan masalah baru. Sampah-sampah yang dibakar akan menghasilkan racun berbahaya bagi kesehatan tubuh manusia, mengakibatkan kanker pada paru-paru serta melemahkan sistem kekebalan tubuh manusia.

Pada awalnya dalam mengatasi permasalahan sampah yang terjadi di Kabupaten Dompu, sudah didirikan Bank Sampah We Save yang didirikan oleh pendiri We Save itu sendiri yaitu Agus Setiawan. Bank sampah We Save merupakan Bank sampah induk yang ada di Dompu dengan harapan generasi

\footnotetext{
${ }^{1}$ Joflius Dobiki, “Analisis Ketersedian Prasarana Persampahan Di Pulau Kumo Dan Pulau Kakara Di Kabupaten Halmahera Utara”, Jurnal Spasial, No 2, Vol 5 (2018)

2Ismail Putra Munthe, "Kontribusi Bank Sampah Dalam Pemberdayaan Masyarakat Desa Kolam" (“Skripsi”, Universitas Islam Negeri Sumatera Utara, Medan, 2018), 9.
} 
muda dapat menjadikannya sebagai peluang bisnis yang menjajikan, sehingga kelestarian dan lingkungan tetap terjaga dengan baik. ${ }^{3}$ Dengan adanya Bank sampah ini diharapkan bisa membangkitkan kesadaran. Lewat bank sampah ini masyarakat Dompu bisa ikut memanfaatkan serta mengelola sampah menjadi sesuatu yang bermanfaat yang bisa menambah kebutuhan ekonomi rumah tangga daripada harus membuang sampah sembarangan begitu saja sehingga sampah yang sudah menumpuk akan menimbulkan berbagi dampak permasalahan bagi pencemaran lingkungan.

Mengamati persoalan tersebut pemuda-pemuda dari Yayasan We Save yang dipimpin oleh Abu Dzar, salah satu pemuda inspiratif Indonesia, yang berasal dari daerah kecil kabupaten Dompu ini berinisiatif untuk mendirikan sekolah berbasis sampah yang diberi nama SMK KREATIF INTERNATIONAL ISLAMIC SCHOOL DOMPU. Sekolah ini merupakan wujud dari kepedulian pemuda terhadap kondisi daerahnya yang dipenuhi oleh sampah. ${ }^{4}$

SMK We Save Creative International Islamic School ini merupakan sebuah sistim pendidikan yang dibayar dengan sampah yang memiliki 3 (Tiga) nilai atau manfaat seperti Edukasi, Ekologi dan Ekonomi yang disingkat dengan 3E. ${ }^{5}$ Pertama, nilai edukasi, yang dimaksud yaitu bagaimana sekolah berbasis sampah mampu memberikan pendidikan langsung kepada siswa serta memberi contoh pembiasaan agar tidak membuang sampah sembarangan, mereka diberi pemahaman terkait dengan jenis-jenis sampah serta cara mengelolanya dengan baik. Kedua, nilai ekologi, terletak pada pemahaman untuk menjaga lingkungan, bahwasannya kebiasaan buruk membuang sampah sembarangan dapat menimbulkan kerusakan lingkungan seperti contoh membuang sampah pada sungai yang dapat mencemarkan air, sampah tersebut yang juga kemudian dimakan oleh ikan dapat merusak ikan-ikan yang berada di sungai hingga berujung pada memburuknya rantai makanan yang akan sampai pada manusia itu sendiri. Ketiga nilai ekonomi, yaitu bagaimana sampah tersebut dapat bernilai bagi para siswa. Ketika sebagian besar masayarakat memandang sampah adalah masalah dan hal menggangu yang kotor, maka bagi siswa SMK Kreatif International Islamic School sampah adalah uang. Dengan program berbasis sampah, sekolah ini hadir sebagai salah satu solusi untuk meringankan beban ekonomi orang tua dalam membiayai sekolah anak-anaknya.

\footnotetext{
3“Bupati HBY Dan Pegadaian Resmikan Bank Sampah Induk We Save”, Dalam http/ / www. Suarantb. Net/Artikel, Diambil Tanggal 6 Juli, Tahun 2021 Pukul 19.35 Wita.

${ }^{4} \mathrm{Abu}$ Dzar, Ketua Yayasan Smk We Save Creative International Islamic SchoolWawancara, Dompu,19 April 2021

${ }^{5} \mathrm{Abu}$ Dzar, Ketua Yayasan Smk We Save Creative International Islamic School Wawancara, Dompu 23 April 2021
} 


\section{LANDASAN TEORI}

\section{Konsep Umum Manajemen}

\section{Pengertian Manajemen}

Manajemen adalah ilmu dan seni mengatur proses pemanfaatan sumber daya manusia dan sumber-sumber lainnya secara efektif dan efesien untuk mencapai suatu tujuan tertentu. Manajemen adalah "maneggiare" yang berarti mengendalikan berasal dari bahasa latin manus yang berati tangan. Kata ini mendapat pengaruh dari bahasa Prancis, manege, yang berarti kepemilikan kuda. Sebagian ahli manajemen juga merujuk istilah manajemen ini dari bahasa Prancis kuno yang berarti menagement, yang memiliki arti seni melaksanakan dan mengatur. Namun, sebagian yang lain menganggap bahwa istilah manajemen dari bahasa Inggris berarti menagement, yang berarti memiliki seni melaksanakan dan mengatur dan diambil dari bahasa Italia. Dari sinilah, istilah manajemen kemudian diacukan pada kata to manage dalam bahasa Inggris berati mengatur, mengurus dan mengelola. ${ }^{6}$

\section{Fungsi-Fungsi Manajemen}

Manajemen memiliki beberapa fungsi yaitu:

\section{Planning}

2. Organizing

3. Directing

4. Controlling

5. Decision making

\section{Sampah}

\section{Pengertian Sampah}

Sampah adalah bahan buangan dalam bentuk padat atau semi padat yang dihasilkan dari aktifitas manusia atau hewan yang dibuang karena tidak diinginkan atau digunakan lagi. Menurut kamus besar bahasa Indonesia (KBBI) sampah berati barang atau benda yang dibuang karena tidak terpakai lagi berupa kotoran seperti daun, dan kertas.

Sampah menurut Undang-undang Republik Indonesia No 18 Tahun 2008 tentang Pengelolaan Sampah, didefinisikan bahwa sampah adalah sisa kegiatan sehari-hari manusia dan proses alam yang berbentuk padat. Sampah didefinisikan sebagai suatu benda yang tidak digunakan atau tidak dikehendaki dan harus dibuang, yang dihasilkan oleh kegiatan manusia. ${ }^{7}$

${ }^{6}$ Lilis Sulastri, Manajemen, (Yogyakarta: La Goods Publishing, 2014),10.

7Yusa Eko Saputro, "Pengelolan Sampah Berbasis Masyarakat Melalui Bank Sampah", Indonesian Jurnal Of Coversation, No. 1, Volume 4 (Mei, 2015), 84. 


\section{Jenis-Jenis Sampah}

1. Sampah organik

2. Sampah non-organik

\section{Metodelogi Penelitian}

Secara umum jenis penelitian yang digunakan dalam penelitian ini adalah penelitian kualitatif dengan metode deskriptif karena memiliki cara untuk menunjukkan sebuah benda, kejadian dan keadaan dimana si peneliti harus menyerahkan hasil penyelidikan tersebut dalam bentuk laporan penelitian berupa kata-kata lisan maupun tulisan tanpa harus mempengaruhi objek yang diteliti. Metode penelitian kualitatif sering disebut sebagai metode naturalistic karena penelitiannya dilakukan pada kondisi yang alamiah dan disebut juga sebagai metode ednographi, karena pada awalnya metode ini lebih banyak digunakan untuk penelitian bidang antropologi budaya. Disebut metode kualitatif, karena data yang terkumpul dan analisisnya lebih bersifat narasi deskriptif. Metode penelitan kulitatif digunakan untuk mendapatkan data yang mendalam, suatu data yang mengandung makna. Makna di balik data yang tampak.

Sumber datanya mencakup data primer dan data sekunder, dengan teknik pengumpulannya menggunakan wawancara, observasi, dan dokumentasi melalui instrumen-instrumennya. Peneliti menggunakan cara berfikir induktif untuk menganalisis data yaitu pengambilan kesimpulan dimulai dari pernyataan atau fakta-fakta khusus menuju kesimpulan yang bersifat umum. ${ }^{8}$ Selanjutnya, uji kredibilitas datanya melalui perpanjang pengamatan, meningkatkan ketekunan, dan triangulasi sumber.

\section{HASIL DAN PEMBAHASAN}

\section{Penyajian Data}

Penyajian data merupakan salah satu kegiatan dalam pembuatan laporan hasil penelitian yang telah dilakukan agar data yang telah dikumpulkan dapat dipahami dan dianalisis sesuai dengan tujuan yang diinginkan. ${ }^{9}$

Adapun beberapa cara penyajian data sebagai berikut:

\section{Aspek Perencanaaan}

1. Proses pengelolaan sampah yang dibawa oleh siswa

Berdasarkan hasil pengamatan peneliti, bahwa aspek perencanaan dimulai dari proses pengelolaan sampah yang dibawa oleh siswa yaitu dimulai dari siswa memilah sampah dari rumah untuk dibawa ke sekolah,

8Nana Sudjana, Tuntunan Penyusunan Karya Ilmiah,(Bandung: Sinar Baru Algosindo, 2011), 7.

${ }^{9}$ Kelas Pintar. Penyajian Data, Pengertian Dan Pengumpulan Data, Https//www.slideshare.Net, Diambil Pada 16 September 2021, Pukul 20:38 Wita. 
lalu mengisi absensi sampah. Sampah kemudian disimpa di tempatnya masing-masing (organik dan anorganik). Sampah anorganik kemudian akan dipilih menjadi kreatifitas dan dalam proses pembuatan sampah menjadi barang kreatifitas yang bernilai tinggi memerlukan waktu yang cukup lama karna dalam pembuatan tersebut memerlukan SDM yang banyak. Hasil pengamatan peneliti didukung oleh hasil wawancara peneliti bersama Bapak Adhar Apriato selaku kepala sekolah dan Bapak Syamsudin selaku ketua Bank Sampah, Pemilik Sekolah, yang mengatakan:

"Sebelum sampah tersebut dimasukan ke karung, sampah tersebut akan dipilah, dipisahkan antara sampah organik dan anorganik terlebih dahulu. Kemudian disusun rapi. Dari sampah-sampah Anorganik tersebut dapat dijadikan kreatifitas oleh siswa yang cukup lama proses pembuatannya sedangkan sampah organik dapat dijadikan untuk tanaman di lahan sekolah. Kemudian hasil dari kreatifitas tersebut akan dijual dan di promosikan di akun media sosila ataupun pameran dan promosi di beberapa negara, dan dalam pencapaian hasil pendapatan yang memuaskan itu memerlukan waktu yang panjang karena tidak mudah mendapatkan pendapatan yang memuaskan."

2. Harga dan Pendapatan tiap bulannya dari hasil sampah

Berdasarkan data yang didapatkan oleh peneliti, bahwa pendapatan yang didaptkan perbualan senilai Rp. 747.000. Pendapatan hasil sampah tersebut didapatkan dari penjualan sampah ke bank induk We Save dan belum termasuk ke dalam hasil penjualan sampah yang sudah dijadikan sebuah kreatifitas.

Tabel 1. Rincian Pendapatan Per Jenis Sampah

\begin{tabular}{|c|c|c|c|c|}
\hline No & Jenis Sampah & Jumlah Kg & Harga/Kg & Jumlah Akhir \\
\hline 1. & Aqua Botol & $10 \mathrm{Kg}$ & Rp. 2.000 & Rp. 20.000 \\
\hline 2. & Aqua Gelas & $152 \mathrm{Kg}$ & Rp. 3.500 & Rp. 532.000 \\
\hline 3. & Gelas Montea & $78 \mathrm{Kg}$ & $\operatorname{Rp} 2.500$ & Rp. 152.000 \\
\hline
\end{tabular}

Hal tersebut juga diperoleh dari pernyataan peneliti bersama bapak Adhar Aprianto, yang mengatakan:

"Pendapatan yang dihasilkan oleh SMK kreatif International Islamic School

Dompu bisa mencapai Rp. 1.051.000/2 bulan bahkan bisa lebih"

Harga sampah yang dibawa oleh siswa setiap harinya ke sekolah menurut hasil observasi/pengamatan penulis adalah seharga Rp. 3000/Kg dan untuk mencapai $1 \mathrm{Kg}$ maka dibutuhkan 300 buah sampah. Hal ini 
berdasarkan hasil wawancara penulis bersama bapak Agus Setiawan, yang mengatakan:

“Harga sampah/Kg senilai Rp. 3000, jika sampah tersebut berjenis botolbotol minuman, dan adapun sampah yang dibawa oleh siswa setiap harinya berjumlah 50 buah, untuk mendapatkan $1 \mathrm{Kg}$ memerlukan 300 buah sampah"

Berdasarkan pernyataan di atas dari hasil jawaban bapak Agus, maka peneliti menyimpulkan bahwa sampah yang wajib dibawa oleh siswa setiap harinya sejumlah 50 buah dan harga sampah/Kg senilai Rp 3.000 sama dengan 300 buah sampah jenis berjenis gelas minuman plastik. Sampahsampah yang dibawa oleh siswa tersebut adalah sebagai bentuk pembayaran SPP, dimana dalam hal ini, setiap siswa diwajibkan untuk membawa sampah setiap harinya ke sekolah, dan jika ada yang tidak mampu membawanya maka akan dikenakan denda senilai Rp.5.000, dan jika tidak mampu membayar denda maka akan diperintahkan untuk pergi mengumpulkan sampah detik itu juga, barulah mereka bisa mengisi absensi sebagai syarat masuk kelas.

3. Cara pemasaran produk hasil sampah

Berdasarkan hasil pengamatan peneliti, cara sekolah melakukan promosi barang sampah yang sudah dijadikan sebuah kreatifitas adalah lewat promosi di akun sosial media berupa Facebook, Youtube maupun WhatsAap. Hal tersebut didukung atas hasil wawancara peneliti bersama bapak Adhar Aprianto, yang mengatakan:

"Cara pemasaran produk hasil sampah dilakukan dengan 3 cara yaitu melakukan promo lewat media sosial seperti FB dan WA, lewat beberapa pameran, dan ketika melakukan kegiatan praktek bahasa Inggris di pantai Lakey, disana kami akan mempromosikan produk tersebut pada warga asing dan pendapatan dari hasil sampah tersebut kemudaian akan dialokasi untuk 3 hal."10

4. Pengalokasian Sampah

Berdasarkan hasil data yang didapatkan oleh peneliti bahwa pengalokasian sampah akan dialokasikan untuk 3 hal yaitu:

a. $40 \%$ Hononarium guru dan pegawai

b. $30 \%$ Operasional Sekolah

c. $30 \%$ Program-Program Sekolah

\section{Aspek Organisasi}

Berdasarkan hasil pengamatan peneliti bahwa dalam proses pengelolaan sampah tersebut masing-masing dibagi tugasnya sesuai dengan penanggung

\footnotetext{
10Adhar Aprianto, Wawancara, Dompu 12 September 2021.
} 
jawab masing-masing dan hal tersebut tertera dalam struktur organisasi bank sampah milik sekolah. Pernyataan ini juga didukung oleh hasil wawancara peneliti bersama bapak Adhar Aprianto yang megatakan bahwa:

"Setiap anggota memiliki tugas dan tanggung jawab masing-masing sesuai dengan yang ditetapkan dalam struktur organisasi, selain itu dalam proses pengelolaan sampah tersebut harus ada yang namanya saling membantu seperti dalam proses pemilahan sampah antara sampah organik dan anorganik, hal itu bukan saja dilakukan oleh ketua bank sampah tapi juga bisa dibantu oleh setiap siswa dan guru. ${ }^{11}$

\section{Aspek Penggerakan}

Berdasarkan pengamatan peneliti dalam aspek penggerakan tentu dengan melakukan kegiatan inovasi. Kegiatan ini adalah kegiatan yang sangat luar biasa, kegiatan ini diadakan setiap hari sabtu, dimana dalam kegiatan ini, siswa dilatih untuk memanfaatkan sampah sebagai sebuah lahan bisnis dengan cara menjadikannya barang yang memiliki nilai tinggi. Hal ini didukung oleh hasil wawancara peneliti bersama salah satu guru SMK Kreatif Dompu International Islamic School yang bernama Ibu Nurul Fitrah Islamiah. Beliau mengatakan:

“Kegiatan ini merupakan salah satu jenis mata pelajaran yang ada di sekolah ini, yaitu mata pelajaran inovasi, dan pelajaran ini dilaksanakan setiap hari sabtu. Jadi setiap hari sabtu kami akan mengajarkan kegiatan inovasi tersebut untuk melatih kreatifitas siswa dalam memanfaatkan sampah, dan mata pelajaran ini diajarkan oleh guru mata pelajaran ini yang juga merupakan ketua Bank Sampah dan salah satu guru yaitu Bapak Iwan Setiawan”. ${ }^{12}$

\section{Aspek Pengawasan}

Berdasarkan pengamatan peneliti bahwa dalam proses pengelolaan sampah seperti pemilahan sampah dan pembuatan sampah menjadi barang kreatifitas tersebut diawasi langsung oleh beberapa guru, salah satunya Bapak Sayamsudin yang juga merupakan ketua bank sampah, karena beliau jugalah yang mengajarkan pelajaran inovasi dimana siswa-siswa tersebut diajarkan untuk memanfaatkan sampah menjadi sebuah lahan bisnis serta melihat kembali hasil dari catatan-catatan laporan keuangan dari pemasukan sampah seperti hasil timbangan ataupun penjualan barang kreatifitas. Hal ini didukung oleh hasil wawancara peneliti bersama Ibu Nurul Fitrah Islamiah yang mengatakan:

“......agar saya bisa mengawasi langsung proses pengelolaan tersebut dan salah satu guru yaitu Bapak Iwan Setiawan”. ${ }^{13}$

11Adhar Aprianto, Wawancara, Dompu 5 Desember 2021.

12Nurul Fitrah Islamiah, Wawancara, Dompu 08 November 2021

13Nurul Fitrah Islamiah, Wawancara, Dompu 08 November 2021 


\section{Aspek Evaluasi}

Berdasarkan hasil wawancara peneliti bersama bapak Adhar Aprianto Selaku Kepala Sekolah mengatakan:

"Bahwa proses evaluasi akhir dilakukan setiap bulan dari hasil pemilahan serta kreatifitas sampah. Evaluasi tersebut dilakukan untuk menilai serta melihat kembali hasil dari kinerja pengelolaan sampah tersebut agar bisa diketahui apa saja yang masih kurang dalam proses pengelolaan sampah tersebut"

\section{Analisis Data}

\section{Bagaimana Manajemen Pengelolaan SMK Berbasis Sampah di SMK Kreatif International Islamic School.}

1. Perencanaan

Perencanaan jangka pendek dalam pengelolaan sampah yang dilakukan oleh SMK Kreatif Dompu International Islamic School sebagaimana pada umumnya, yaitu melaksanakan proses pengelolaan sampah dimulai dari penyetoran sampah dari masyarakat yang dibawa oleh siswa-siswa SMK untuk mengumpulkan botol-botol minuman, kardus, dan bungkusanbungkusan minuman serta sampah yang dapat dijadikan kreatifitas dan akan dipromosikan untuk dijual di masyarakat.

Perencanaan jangka menengah, mengenai penggunaan sampah tersebut akan di kreasikan seperti apa. Dalam proses penginovasian sampahsampah tersebut, siswa-siswa diajarkan dan dilatih untuk membuat perubahan terhadap sampah-sampah tersebut menjadi barang yang bernilai ekonomi tinggi. Seperti membuat tas, dompet, tempat tisu dan tempat untuk menaruh minuman.

Perencanaan jangka panjang, program sekolah dalam melakukan pengeloaan sampah yaitu melakukan sebuah promosi hasil kreatifitas lewat media sosial ataupun melakukan promosi dengan beberapa negara seperti Australia dan Malaysia. Karena memang pada umumnya organisasi We Save serta SMK-nya sudah dikenal dibeberapa negara bahkan sering diundang keluar Negeri, sehingga dengan mudah mereka berkomunikasi untuk melakukan promosi barang-barang sampah yang dijadikan kreatifitas bernilai tinggi terhadap negara-negara tersebut untuk dijual dengan harga tinggi.

2. Fungsi Pengorganisasian

Berdasarkan hasil penelitian penulis spesialisasi kegiatan berkenaan dengan spesifikasi tugas-tugas yang dilakukan oleh siswa-siswa dan guru sudah tertata dengan teratur. Sebagaimana struktur keorganisasian yang dibagi ke dalam 4 bagian yaitu ketua, sekretaris, bendahara, dan 
penanggung jawab pengeloaaan sampah. Empat bagian tersebut memiliki tugas dan tanggung jawab masing-masing

3. Fungsi penggerakan

Berdasarkan hasil penelitian penulis, Sekolah SMK Kratif Dompu International Islamic School dalam menggerakan siswa-siswanya untuk lebih peduli terhadap lingkungan dengan melakukan pengajaran dengan beberapa tahap, yaitu tahap penyadaran terhadap siswa dan guru akan pentingnya menjaga lingkungan dan tahap belajar dalam mengelola sampah yang baik dan benar.

4. Fungsi Pengawasan

Pengawasan yaitu proses yang dilakukan untuk memastikan seluruh rangkaian kegiatan yang telah direncanakan, diorganisasikan, dan diimplementasikan bisa berjalan sesuai dengan target yang diharapkan, sekalipun berbagai perubahan terjadi dalam lingkungan dunia bisnis yang dihadapi. Pengawasan pengelolaan sampah yang dilakukan oleh SMK Kreatif Dompu International Islamic School masih sederhana, yaitu dengan melihat hasil dari kreatifitas-kreatifitas pembuatan sampah yang dilakukan oleh siswa, dana hasil dari sampah yang terjual seberapa banyak, serta pendapatan yang dihasilkan selama perbulan hingga pertahun dengan melihat hasil pencatatan laporan.

5. Fungsi Evaluasi

Berdasarkan hasil penelitian penulis, evaluasi pengelolaan sampah yang dilakukan oleh SMK Kreatif International Islamic School Dompu yaitu dengan melihat dan menilai kembali hasil dari kinerja manajemen pengelolaan sampah tersebut, mengoreksi serta menilai kembali apa saja yang kurang dalam memanajemen pengelolaan sampah tersebut. Tujuan dilakukannya fumgsi evaluasi ini untuk memperoleh informasi tentang perencanaan dan pelaksanaan dalam proses pengelolaan sampah, untuk memperbaiki kebijakan perencanaan dan pelaksanaan program, serta untuk memperbaiki alokasi sumber daya manajemen.

\section{KESIMPULAN}

Hasil penelitian dengan judul Analisis Manajemen Pengelolaan SMK Berbasis Sampah di SMK Kreatif Dompu International Islamic School:

1. Perencanaan
a. Jangka Pendek
b. Jangka Menengah
c. Jangka Panjang 
2. Organisasi

Organisasi dalam hal ini adanya struktur keorganisasian yang dibagi ke dalam 4 bagian yaitu ketua, sekretaris, bendahara, dan penanggung jawab pengeloaaan sampah. Empat bagian tersebut memiliki tugas dan tanggung jawab masing-masing. Pada pelaksanaannya mereka harus saling membantu satu sama lain.

3. Penggerakan

Penggerakan disisni adalah adanya sebuah tindakan membimbing, mengarahkan, menggerakkan para siswa dan bagian penanggung jawab pengelolaan sampah agar mau bekerja secara baik dan benar.

4. Pengawasan

Pengawasan pengelolaan sampah yang dilakukan oleh SMK Kreatif Dompu International Islamic School masih sederhana, yaitu dengan melihat hasil dari kreatifitas-kreatifitas pembuatan sampah yang dilakukan oleh siswa, dana hasil dari sampah yang terjual seberapa banyak, serta pendapatan yang dihasilkan selama perbulan hingga pertahun dengan melihat hasil pencatatan laporan.

5. Evaluasi

Evaluasi pengelolaan sampah yang dilakukan oleh SMK Kreatif International Islamic School Dompu yaitu dengan melihat dan menilai kembali hasil dari kinerja manajemen pengelolaan sampah tersebut, mengoreksi serta menilai kembali apa saja yang kurang dalam memanajemen pengelolaan sampah tersebut.

Berdasarkan paparan di atas peneliti dapat menyimpulkan bahwa manajemen pengelolaan sampah oleh SMK Kreatif International Islamic School telah dilakukan secara efektif dan memenuhi unsur-unsur manajemen walaupun ada beberapa yang belum dilaksanakan secara baik seperti kurangnya pencatatan pemasukan dari hasil sampah. 


\section{DAFTAR PUSTAKA}

Bupati HBY Dan Pegadaian Resmikan Bank Sampah Induk We Save, Dalam http//www. Suarantb. Net/Artikel, Diambil Tanggal 6 Juli, Tahun 2021Pukul 19.35 Wita.

Ismail Putra Munthe, “Kontribusi Bank Sampah Dalam Pemberdayaan Masyarakat Desa Kolam” (“Skripsi”, Universitas Islam Negeri Sumatera Utara, Medan, 2018)

Joflius Dobiki, "Analisis Ketersedian Prasarana Persampahan Di Pulau Kumo Dan Pulau Kakara Di Kabupaten Halmahera Utara", Jurnal Spasial, No 2, Vol 5 (2018)

Kelas Pintar. Penyajian Data, Pengertian Dan Pengumpulan Data, Https//www.slideshare.Net, Diambil Pada 16 September 2021, Pukul 20:38 Wita.

Lilis Sulastri, Manajemen, (Yogyakarta: La Goods Publishing, 2014)

Nana Sudjana, Tuntunan Penyusunan Karya Ilmiah,(Bandung: Sinar Baru Algosindo, 2011)

Yusa Eko Saputro, "Pengelolan Sampah Berbasis Masyarakat Melalui Bank Sampah", Indonesian Jurnal Of Coversation, No. 1, Volume 4 (Mei, 2015) 